\title{
Factors affecting white clover persistence in New Zealand pastures
}

\author{
D.R. WOODFIELD and J.R. CARADUS \\ AgResearch Grasslands, Private Bag 11008, Palmerston North
}

\section{Abstract}

Better persistence and reliability of white clover (Trifolium repens L.) is critical in achieving a more competitive New Zealand farming industry. To persist, white clover must establish well and withstand the accumulated stresses of competition from associated grasses, grazing, variable soil fertility, drought, plus pest and disease pressure. These factors vary markedly with environment and farming system, making the choice of appropriate grazing management, plant nutrition, companion species and cultivar difficult. White clover is particularly vulnerable to mismanagement and environmental stresses during spring when plant size is at its smallest. This vulnerability is further compounded by the current trend in dairying to apply high rates of nitrogen $(\mathrm{N})$ which favours grass growth more than clover growth. A faster grazing rotation and/or higher stocking rates can offset the adverse effects of $\mathrm{N}$ on white clover by utilising the additional grass produced and reducing competition for light. Irrespective of $\mathrm{N}$ inputs, frequent defoliation during spring favours white clover persistence by increasing grass tiller density, resulting in better ground cover and in lower soil surface temperatures in summer. There is a threshold above which the density of associated grass suppresses clover growth. This is most prevalent in swards containing browntop, cocksfoot and kikuyu, which are more competitive against white clover than tall fescue, timothy and perennial ryegrass. Plant breeding efforts to improve persistence concentrate on increasing the rate of stolon formation and decreasing the rate of stolon death. These efforts include selecting genotypes that have better spread and persistence in association with different grasses, and genotypes that continue to grow with lower inputs of phosphate. Changes in root morphology have enhanced persistence under moderate drought stress, while significant improvements in resistance to clover cyst nematode, root-knot nematode and clover flea offer real hope in reducing the impact of these pests. Developing cultivars with higher stolon growing point densities at a particular leaf size should improve persistence while maintaining the greater yield potential.

Keywords: climatic stresses, competition, diseases, grazing management, pests, plant breeding, plant nutrition, Trifolium repens $\mathrm{L}$.

\section{Introduction}

White clover (Trifolium repens L.) is an essential component in the vast majority of New Zealand pastures, contributing to animal performance, improving the quality of consumed herbage, and improving soil fertility through nitrogen fixation. Indeed the value of these to New Zealand's economy has been estimated at about $\$ 3.1$ billion annually (Caradus et al. 1996). However, despite its undoubted agronomic and economic value, better persistence and reliability of white clover is a critical requirement in the development and release of any new cultivars (Mather et al. 1996).

Persistence of white clover can be assessed as survival of individual plants or as maintenance of clover content per unit area. White clover is a perennial species, but its seedling tap-root does not persist for more than two years under dry conditions and persists for less than 18 months under moist conditions (Westbrooks \& Tesar 1955; Charlton et al. 1989). Once the seedling tap-root begins to die, white clover relies on stolons and their associated nodal roots to persist. When the rate of stolon removal or death is higher than the rate of stolon renewal, the size of individal plants and stolons decreases, fewer plants persist and clover content decreases. Under New Zealand hill country conditions less than $10 \%$ of stolons survive for longer than 12 months, emphasising the need for continual renewal of the stolon mass and adequate nodal root survival if white clover is to persist under grazing (Chapman 1983).

The major factors that influence persistence can be divided into those that primarily affect the rate of stolon and nodal root formation and those that influence the rate of stolon and nodal root death. Grazing, plant nutrition and competition can be managed to improve the rate of stolon and nodal root formation in white clover, while drought stress, disease and insect pests accelerate the rate of stolon death. Plant breeding aims to improve persistence by increasing the rate of stolon 
formation and decreasing the rate of stolon death. This paper reviews the effect of each these factors on white clover persistence and summarises the breeding and management efforts to improve persistence. Many of the studies reviewed do not have detailed information on stolon formation and death, and in these cases clover content is predominantly used as the measure of persistence.

\section{Grazing management}

White clover is particularly vulnerable to mismanagement and environmental stresses during spring when the size of individual plants is at its smallest (Brock \& Hay 1993). During winter up to $90 \%$ of the stolon mass can be buried by the combined action of stock treading and earthworms (Hay et al. 1987). New stolons are produced in early spring and once they become established above the soil surface, older stolons and their associated roots start to die. This causes large plants to break up into many smaller clonal units (Brock et al. 1988). Stolon death frequently exceeds stolon growth in spring and plant size decreases. This reduction in plant size is occurring as the companion grasses are growing most actively, and the frequency and intensity of defoliation become critical factors in the persistence of these white clover plants. Frequent grazing during spring favours the growth and survival of white clover under both sheep and cattle grazing (Brougham 1960; Bryant 1991; Brock et al. 1988). More frequent defoliation reduces competition for light and leads to much higher stolon growing point densities (Brock \& Hay 1996).

In late spring and early summer plant size and complexity (i.e higher orders of stolon branching) increase rapidly and rates of stolon formation and death reach a balance, which is generally maintained until late winter. During this period soil moisture stress can disrupt this balance by slowing the rate of stolon growth and causing rapid loss of existing stolons. A clear interaction exists between grazing management and drought stress. Brock (1988) showed that under set-stocking there was very little reduction in stolon mass or clover content during a spring drought but under rotational grazing there was a $75-90 \%$ reduction in stolon mass and clover content decreased from $15 \%$ to $2 \%$. This interaction was attributed to a combination of grass tiller density and soil surface temperatures. The higher grass tiller density in set-stocked pastures provided greater protection from direct solar radiation and reduced soil surface temperatures in summer. Brock \& Hay (1993) reported soil surface temperatures of $40^{\circ} \mathrm{C}$ for setstocked pastures versus $48^{\circ} \mathrm{C}$ for rotationally grazed pastures. Buried stolons also benefit from shading and influence persistence (Brock \& Kim 1994). Grazing managements such as set-stocking during spring, which encourages higher grass densities during summer, or deferred grazing, which increases stolon shading in summer, can improve clover persistence by reducing the soil surface temperatures and conserving soil moisture (Brock \& Kim 1994; Watson et al. 1996). In addition the type of stock also affects the outcome of grazing in the summer. More frequent grazing with dairy cows in summer can be advantageous (Bryant 1991), but less frequent defoliation with sheep is recommended to avoid removing excessive amounts of stolon (Brougham 1960).

The development of new stolon branches is controlled by light conditions experienced at the node from which the stolon develops (Robin et al. 1994). Shading reduces the intensity and quality of radiation reaching the node and leads to fewer branched nodes and less well developed stolons (Thompson 1993).

Heavy treading reduces the yield of white clover in both monocultures or in mixed swards, and this effect is greater at higher stocking rates and in winter when soils are wet (Edmond 1964).

\section{Competition}

Grasses that form a denser sward such as browntop, cocksfoot and kikuyu tend to adversely affect white clover persistence more than grasses that form less-dense swards such as tall fescue, meadow fescue, timothy and perennial ryegrass. As tiller density increases even the most compatible grasses can reduce white clover persistence. Furthermore, management practices that increase tiller density, such as longer defoliation intervals and nitrogen fertiliser, will also reduce white clover persistence.

Tiller density plays an important role in influencing the rate of stolon formation and thereby clover content. Tiller densities under dairying are generally lower than those for rotational grazing by sheep, owing to reduced grazing pressure, and the decreased competition encourages higher clover contents. Brereton et al. (1985) showed that as grass tiller densities increased above 5000 tillers $/ \mathrm{m}^{2}$ clover content decreased. This contrasts with clover contents under various grazing managements. Tiller density is often $5-6000$ tillers $/ \mathrm{m}^{2}$ under rotational grazing and $11-15000$ tillers $/ \mathrm{m}^{2}$ under setstocking but clover content is often higher in set-stocked pastures (Brock \& Hay 1993).

Endophyte-containing ryegrasses are more resistant to Argentine stem weevil, have better persistence and higher yields than endophyte-free ryegrasses, but they are more competitive against white clover and can reduce clover yield and persistence (Sutherland \& Hoglund 1989). 
Figure 1 Factors affecting white clover persistence and interactions between these factors.

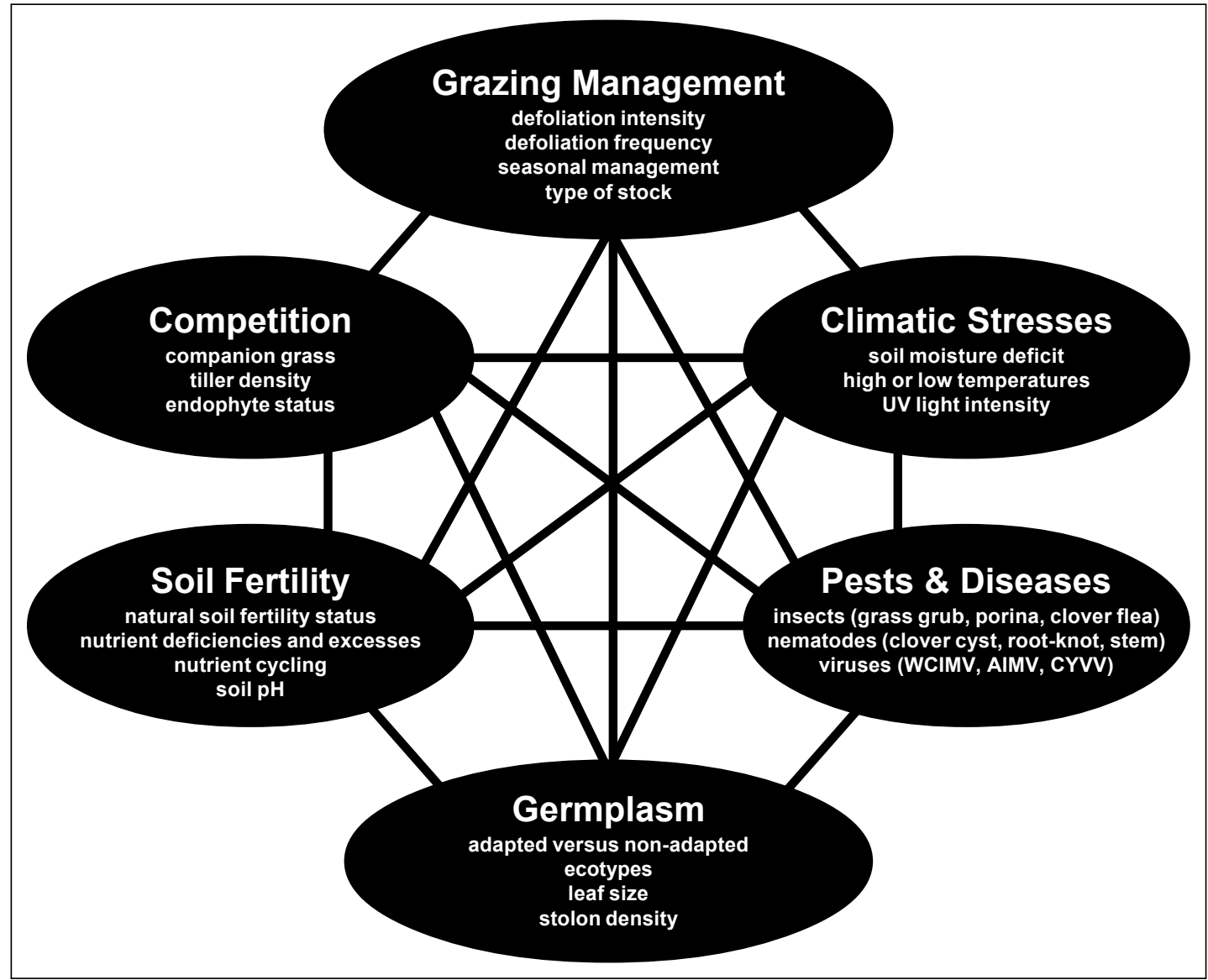

Plant breeding efforts aim to improve competitive ability through (i) better stolon growth by selecting genotypes that have better spread in association with grasses such as perennial ryegrass, tall fescue, cocksfoot, browntop and kikuyu; and by selecting genotypes that grow better in shade, (ii) by identifying critical morphological characteristics such as different stolon and root morphologies which improve persistence (Caradus \& Chapman 1996; Woodfield 1994), and (iii) improved adaptation to low soil fertility and $\mathrm{pH}$.

\section{Plant nutrition}

White clover persists best on soils that range from moderately-low to high fertility, but many New Zealand soils have low natural soil fertility (Levy 1970). Phosphorus is the major limiting nutrient for white clover in most soils, followed by sulphur (S), potassium (K) and molybdenum (Mo) (During 1984). White clover is a poorer competitor for $\mathrm{P}, \mathrm{K}$, and $\mathrm{S}$ than its companion grasses, although it becomes more competitive as soil fertility increases. Management practices can further exacerbate this by increasing grass competition and thereby shading the clover. Most soils require annual maintenance inputs of $\mathrm{P}$ and $\mathrm{S}$ to ensure adequate clover growth, while additional $\mathrm{K}$ is necessary in more intensive grazing systems such as dairying. Maintenance requirements of these nutrients increase as stocking rate increases (Roberts et al. 1994).

Topdressing with $\mathrm{P}$ and $\mathrm{K}$ slightly extended the persistence of the seedling tap-root, but not beyond 24 months (Westbrooks \& Tesar 1955). Genotypes that continue to grow with low inputs of phosphate are being selected in order to provide white clover cultivars that are more competitive and therefore productive and persistent in lower fertility situations.

Phosphate and sulphate fertilisers are applied mainly to stimulate white clover growth so that adequate $\mathrm{N}$ is fixed and made available for grass growth. However, N levels are still deficient in many New Zealand pastures. 
This has increasingly led to the application of additional fertiliser $\mathrm{N}$, which can adversely affect white clover persistence at levels as low as $100 \mathrm{~kg} \mathrm{~N} / \mathrm{ha}$ (O'Connor 1982). The current trend in New Zealand dairying has been to apply rates as high as $400 \mathrm{~kg} \mathrm{~N} / \mathrm{ha}$, and at these high rates clover content is severely reduced (Harris et al. 1996). At intermediate levels of $\mathrm{N}(100-200 \mathrm{~kg}$ $\mathrm{N} / \mathrm{ha} / \mathrm{yr}$ ) a higher stocking rate can prevent this loss in clover content because the additional forage produced is better utilised and the clover receives less shading (Harris et al. 1996).

Lime is generally required for white clover establishment when the soil $\mathrm{pH}$ is less than 5.0. Once established, white clover can tolerate soil $\mathrm{pH}$ as low as 4.0, but optimum growth occurs around $\mathrm{pH} 5.5$ to 5.8 (Edmeades et al. 1984). At low $\mathrm{pH}$, nodulation and $\mathrm{N}$ fixation can be affected, and clover yield is reduced. Application of lime reduces the toxic effects of aluminium and manganese, and can increase the availability of soil P (During 1984).

The choices by farmers of grazing management, plant nutrition and companion species are therefore important in determining clover content and persistence. These choices vary markedly with environment and farm system.

\section{Climatic stresses}

During summer white clover has a competitive advantage over most cool-season grasses because of its higher optimum temperature for growth; however, this summer growth advantage is realised only when soil moisture is adequate (Harris 1987). White clover, which has a shallow root system, can be susceptible to moisture stress. Plant populations are very susceptible to drought during spring when plant size is at its smallest (Brock 1988), while the more common summer and autumn droughts can cause the death of nodal roots and the collapse of stolon populations (Gibson \& Trautner 1965; Woodfield \& Caradus 1987; Archer \& Robinson 1989). Uneven seasonal rainfall, slope, aspect and waterholding capacity of the soil all contribute to soil moisture deficits. Frequently the combination of high soil surface temperatures and soil moisture deficits results in the collapse of stolon populations (Archer \& Robinson 1989). Root and stolon characteristics are important in plant adaptation to stress. Higher stolon growing point densities, larger tap-roots and higher root to shoot dry matter ratio have been identified as important morphological traits that can be used to breed white clovers with better persistence under short-term moisture deficits (Brock 1988; Woodfield 1994).

The importance of adequate soil moisture for clover growth can be shown from irrigated and non-irrigated comparisons. Irrigation generally increases clover content and persistence if drainage is adequate (Harris 1987). Poor drainage can reduce clover persistence through an increase in root rot diseases and increased susceptibility to damage from stock treading (Hopkins \& Green 1979).

Under extreme conditions recovery from buried stolons or regeneration of the population from buried seed are important persistence mechanisms (Jones \& Evans 1977; Archer \& Robinson 1989). However, selection for profuse flowering can be detrimental to persistence since each node has the potential to produce either a stolon or a flower but not both. High levels of flowering can therefore reduce persistence by reducing stolon density in late spring and summer, making them more susceptible to summer droughts (Gibson 1957).

The interaction between moisture stress and grazing management has already been discussed but there is also an interaction with pest pressure. Feathermark Huia, which contains a dominant leaf marking, was grown for four years at two dry, two moist, and two wet hill country sites (Charlton 1984). The best persistence was at a dry hill country site where levels of root-knot nematode were lower and where cattle grazing maintained better pasture control during the critical spring period.

\section{Pests and diseases}

Pasture pests such as grass grub (Costelytra zealandica), porina (Wiseana spp.), clover cyst nematode (Heterodera trifolii), root-knot nematode (Meloidogyne spp.), stem nematode (Ditylenchus dipsaci), clover flea (Sminthurus viridis), field cricket (Teleogryllus commodus) and slugs can all affect white clover growth and persistence. Viruses are also prevalent in white clover, but only white clover mosaic virus (WCIMV) and alfalfa mosaic virus (AlMV) have been proven to have a significant impact on white clover performance in New Zealand. None of the main fungal pathogens of white clover, clover rust (Uromyces trifolii), sclerotinia rot (Sclerotinia trifoliorum) and pepper spot (Leptosphaerulina trifolii), have been proven to have a significant effect on persistence in New Zealand, although sclerotinia rot has a significant effect in Europe (Skipp \& Hampton 1995).

The incorporation of pest and disease resistance is a critical component of New Zealand breeding programmes. Immunity to clover cyst resistance (van den Bosch \& Mercer 1996b) and increased resistance to root-knot nematode (van den Bosch \& Mercer 1996a) have been achieved through recurrent selection. These resistances should have a substantial impact on white clover growth and persistence, as shown by the $40 \%$ 
increase in clover production when nematicide was applied (Watson et al. 1985). Grazing management and chemical control are effective against grass grub, with set-stocking slowing the invasion and reducing the severity of grass grub (Brock 1986). Resistance to grass grub and porina has not been obtained through conventional breeding efforts, but transgenic white clovers containing proteinase inhibitors are being developed in an attempt to control porina. Stem nematodes and slugs are primarily a problem during pasture establishment while clover flea is a problem in northern New Zealand during spring and autumn. Good levels of resistance to stem nematode and clover flea have been identified in Grasslands Prestige (Cooper \& Chapman 1993). Field crickets are predominantly a problem in northern New Zealand during dry summers, with up to $28 \%$ reduction in pasture production (Blank 1982). Plots treated with an insecticide and a fungicide improved clover content from $12 \%$ in untreated plots to $88 \%$ owing to decreased root and stolon damage (James et al. 1980).

Increasing levels of virus infection were associated with a steady decline in white clover persistence over a 4-year period in southern USA (McLaughlin et al. 1992). WCIMV is endemic in New Zealand, with 4 to $34 \%$ of white clovers tested in Northland and South Island pastures infected, while levels of at least $50 \%$ were detected in the rest of the North Island. The impact of this virus is emphasised by the $24 \%$ yield reduction of white clover detected in glasshouse tests (Guy \& Forster 1995). AlMV incidence is greater in the South Island than in the North Island and has been shown to reduce white clover yield by up to $11 \%$ (Guy \& Forster 1995). The impact of both viruses is greater on $\mathrm{N}$ fixation than on yield per se. Resistance to these common viruses is being tackled by both conventional and molecular approaches. Pederson \& McLaughlin (1994) identified genetic resistance to AlMV, peanut stunt virus (PSV) and clover yellow vein (CYVV), while Pederson \& McLaughlin (1996) also reported the first example of genetic resistance to white clover mosiac virus (WCIMV) in white clover. Several different genes for virus resistances have been transformed into white clover and the first field test of transgenic WCIMV resistant white clovers is currently underway near Palmerston North.

Pests and diseases can directly affect persistence where pest and disease levels are high or indirectly by reducing the competitive ability of white clover. Management practices have little impact on most of the pests and diseases mentioned, and the cost of chemical control is often not economic. Therefore, developing cultivars that are resistant to these pests and diseases remains the primary goal for increasing persistence.

\section{Plant breeding}

Adapted germplasm plays an important role in improving persistence. Ecotypes collected from moist hill country (Grasslands Tahora), dry hill country (Prop), Northland (Grasslands Prestige and Grasslands Challenge), and Southland (Grasslands Demand) were critical in developing our more recent New Zealand cultivars (Caradus et al. 1996).

It is often difficult to ascertain the exact frequency of surviving plants in grazed swards because of the annual break-up of individual plants and regeneration of new seedlings from buried seed; however, clear examples are available of improvements in persistence through plant breeding. In a hill country trial at Ballantrae, $58 \%$ of the plants present in sown plots in hill country were true-to-type after 4 years for Grasslands Tahora compared with $43 \%$ for Grasslands Huia. However, after 8 years these frequencies were $56 \%$ and $14 \%$, respectively (Chapman et al. 1995). Grasslands Tahora also showed better persistence than Grasslands Huia and the resident ecotype at a wet- and a dry-hill country site (Charlton et al. 1989).

Brock \& Caradus (1996) reported (i) a preferential loss of large-leaved genotypes in all cultivars irrespective of grazing management or drought stress and (ii) a general decline in performance occurs about 18 months after sowing, presumably through the demise of the seedling tap-root and the increasing reliance on rooted stolons. The ability to maintain the more productive, larger-leaved genotypes in the population and to either prolong the life-span of the seedling tap-root or, alternatively, to increase the performance of the secondary plants that form after the death of the seedling tap-root, are important research objectives. The role of soil fertility, management and breeding need to be determined.

Dense stolon branching is an important survival mechanism but populations with dense stolon branching frequently can have smaller leaves and lower forage yield potential (Rhodes \& Harris 1979). This balance between productivity and persistence is particularly important. Lee et al. (1994) used cluster analysis to identify populations that were both high yielding and persistent and found Grasslands Sustain (formerly known as "large-leaved stoloniferous") and Grasslands Prestige were the best among 24 populations evaluated. Both of these cultivars were bred for higher stolon growing point densities but without reducing the respective leaf size of the base population from which they were selected (Caradus et al. 1996). This approach appears to improve persistence through higher nodal populations while maintaining the greater yield potential of larger leaf sizes. 


\section{REFERENCES}

Archer, K.A.; Robinson, G.G. 1989. The role of stolons and seedlings in the persistence and production of white clover (Trifolium repens L. cv. Huia) in temperate pastures in the northern Tablelands, New South Wales. Australian journal of agricultural research 40: 605-616.

Blank, R.H. 1982. The pest status of Teleogryllus commodus in New Zealand. Proceedings 3rd Australasian Conference Grassland Invertebrate Ecology, pp. 355-363.

Brereton, A.J.; Carton, O.T.; Conway, A. 1985. The effect of grass tiller density on the performance of white clover. Proceedings International Grassland Congress 15: 756-757.

Brock, J.L. 1988. Evaluation of New Zealand bred white clover cultivars under rotational grazing and set stocking with sheep. Proceedings of the New Zealand Grassland Association 49: 203-206.

Brock, J.L.; Caradus, J.R. 1996. Influence of grazing management and drought on white clover population performance and genotypic frequency. Grassland research and practice series no. 6: 79-82.

Brock, J.L.; Hay, M.J.M., Thomas, V.J.; Sedcole, J.R. 1988. Morphology of white clover (Trifolium repens L.) plants in pastures under intensive sheep grazing. Journal of agricultural science, Cambridge 111: 273-283.

Brock, J.L.; Hay, R.J.M. 1993. An ecological approach to forage management. Proceedings International Grassland Congress 17: 837-842.

Brock, J.L.; Hay, M.J.M. 1996. A review of the role of grazing management on the growth and performance of white clover cultivars in lowland New Zealand pastures. Grassland research and practice series no. 6: 65-70.

Brock, J.L.; Kim, M.C. 1994. Influence of the stolon/ soil surface interface and plant morphology on the survival of white clover during severe drought. Proceedings of the New Zealand Grassland Association 56: 187-191.

Brougham, R.W. 1960. The effect of frequent hard grazing at different times of the year on the productivity and species yields of grass-clover pasture. New Zealand journal of agricultural research 3: 125-136.

Bryant, A.M. 1991. fast rotation = pastures thick with ryegrass, clover; higher solids milk. Dairy exporter (April), p. 24-27.

Caradus, J.R.; Chapman, D.F. 1996. Selection for and heritability of stolon characteristics in two cultivars of white clover. Crop science 36: 900-904.

Caradus, J.R.; Woodfield, D.R.; Stewart, A.V. 1996.
Overview and vision for white clover. Grassland research and practice series no. 6: 1-6.

Chapman, D.F. 1983. Growth and demography of Trifolium repens stolons in grazed hill swards. Journal of applied ecology 20: 590-608.

Chapman, D.F.; Mackay, A.D.; Devantier, B.P.; Dymock, N.; Sanders, K. 1995. Evaluation of Grasslands Tahora white clover in North Island hill country. Reported prepared for Wrightsons Seeds Ltd, August 1995.

Charlton, J.F.L. 1984. Persistence of Grasslands Huia white clover (Trifolium repens L.) in hill country pastures. Proceedings of the New Zealand Grassland Association 45: 131-139.

Charlton, J.F.L.; Woodfield, D.R.; Caradus, J.R. 1989. Performance of Trifolium repens genotypes under grazing in New Zealand hill pasture. Proceedings International Grassland Congress 16: 349-350.

Cooper, B.M.; Chapman, D.F. 1993. Grasslands Prestige (G39), a white clover originating from northern New Zealand. Proceedings International Grassland Congress 17: 458-459.

During, C. 1984. Fertilisers and soils in NZ farming. 3rd edition. Wellington: Government Printer.

Edmeades, D.C.; Pringle, R.M.; Shannon, P.W.; Mansell, G.P. 1984. Effects of lime on pasture production on soils in the North Island of New Zealand. 4. Predicting lime responses. New Zealand journal of agricultural research 27: 371-382.

Edmund, D.B. 1964. Some effects of sheep treading on the growth of ten pasture species. New Zealand journal of agricultural research 7: 1-16.

Gibson, P.B. 1957. Effect of flowering on the persistence of white clover. Agronomy journal 45: 251-257.

Gibson, P.B.; Trautner, J.L. 1965. Growth of white clover with and without primary roots. Crop science 5: 477-479.

Guy, P.L.; Forster, R.L.S. 1996. Viruses of New Zealand grasses and legumes. pp. 289-302. In: Chakraborty, S. et al. (eds). Pasture and forage crop pathology. Madison, Wisconsin: ASA.

Harris, S.L.; Clark, D.A.; Waugh, C.D.; Clarkson, F.H. 1996. Nitrogen fertiliser effects on white clover in dairy pastures. Grassland research and practice series no. 6: 119-124.

Harris, W. 1987. Population dynamics and competition. pp. 203-297. In: Baker, M.J. \& Williams, W.M. (eds). White clover. Farnham Royal, CAB International.

Hay, M.J.M.; Chapman, D.F.; Hay, R.J.M.; Pennell, C.G.L.; Woods, P.W.; Fletcher, R.H. 1987. Seasonal variation in the vertical distribution of white clover stolons in grazed swards. New Zealand journal of agricultural research 30: 1-8. 
Hopkins, A.; Green, J.O. 1979. The effect of soil fertility and drainage on sward changes. British Grasslands Society Occasional Symposium no. 10: 115-129.

James, J.R.; Lucas, L.T.; Chamblee, W.V. 1980. Influence of fungicide and insecticide applications on persistence of Ladino clover. Agronomy journal 72: 781-784.

Jones, R.M.; Evans, T.R. 1977. Soil seed levels of Lotononis bainesii, Desmodium intortum and Trifolium repens in sub-tropical pastures. Journal of the Australian Institute of Agricultural Science 43: 164-166.

Lee, C.K.; Eagles, H.A.; Caradus, J.R.; Reed, K.F.M. 1994. Investigation of yield and persistence of white clover using cluster analyses. Euphytica 72: 219224.

Levy, E.B. 1970. Grasslands of New Zealand. Wellington: Government Printer.

Mather, R.D.J.; Melhuish, D.T.; Herlihy, M. 1996. Trends in global marketing of white clover cultivars. Grassland research and practice series no. 6: 714.

McLaughlin, M.R.; Pederson, G.A.; Evans, R.R.; Ivy, R.L. 1992. Virus disease and stand decline in a white clover pasture. Plant disease 76: 158-162.

Mercer, C.F.; Watson, R.N. 1996. Nematode pathogens of New Zealand pastures. pp. 241-256. In: Chakraborty, S. et al. (eds). Pasture and forage crop pathology, Madison, Wisconsin: ASA.

O'Connor, M.B. 1982. Nitrogen fertilisers for the production of out-of-season grasses. pp. 65-76. In: Lynch, P.B. (ed.). Nitrogen fertilisers in New Zealand agriculture. Auckland: Ray Richards.

Pederson, G.A.; McLaughlin, M.R. 1994. Genetics of resistance to peanut stunt virus, clover yellow vein, and alfalfa mosaic viruses in white clover. Crop science 34: 896-900.

Pederson, G.A.; McLaughlin, M.R. 1996. Inheritance of white clover mosaic virus resistance in white clover. Proceedings Trifolium Conference 14: 13.

Rhodes, I.; Harris, W. 1979. The nature and basis of differences in sward composition and yield in ryegrass-white clover mixtures. British Grasslands Society Occasional Symposium no. 10: 55-60.

Roberts, A.H.C.; Webb, T.H.; Morton, J.D.; O'Connor, M.B.; Edmeades, D.C. 1994. Building a solid foundation - sulphur, phosphorus and potassium requirements for the sedimentary soils of North Canterbury. Proceedings of the New Zealand Grassland Association 56: 7-12.

Robin, C.; Hay, M.J.M.; Newton, P.C.D. 1994. Effect of light quality (red:far red ratio) and defoliation treatments applied at a simple phytomer on axillary bud outgrowth in Trifolium repens L. Oecologia (Berlin) 72: 372-376.

Skipp, R.A.; Hampton, J.G. 1995. Fungal and bacterial diseases of pasture plants in New Zealand. pp. 213236. In: Chakraborty, S. et al. (eds). Pasture and forage crop pathology. Madison, Wisconsin: ASA.

Sutherland, B.L.; Hoglund, J.H. 1989. Effect of ryegrass containing the endophyte (Acremonium lolii), on the performance of associated white clover and subsequent crops. Proceedings of the New Zealand Grassland Association 50: 265-269.

Thompson, L. 1993. The influence of the radiation environment around the node on morphogenesis and growth of white clover (Trifolium repens). Grass and forage science 48: 271-278.

van den Bosch, J.; Mercer, C.F. 1996a. Third generation progress in breeding white clover for resistance to root-knot nematode. Grassland research and practice series no. 6: 163-166.

van den Bosch, J.; Mercer, C.F. 1996b. Breeding pest resistant white clover: progress against the clover cyst nematode. Proceedings of the New Zealand Grassland Association 58: (this volume).

Watson, R.N.; Harris, R.L.; Bell, N.L.; Neville, F.J. 1996. Deferred grazing to enhance white clover content in pastures. Grassland research and practice series no. 6: 154.

Watson, R.N.; Yeates, G.W.; Littler, R.A.; Steele, K.W. 1985. Responses in nitrogen fixation and herbage production following pesticide applications on temperate pastures. Proceedings Australasian Conference Grassland Invertebrate Ecology 4: 101113.

Westbrooks, F.E.; Tesar, M.B. 1955. Tap-root survival of ladino clover. Agronomy journal 47: 403-410.

Woodfield, D.R. 1994. Root morphology and its influence on drought tolerance in white clover. Agronomy abstracts. p. 103.

Woodfield, D.R.; Caradus, J.R. 1987. Adaptation of white clover to moisture stress. Proceedings of the New Zealand Grassland Association 48: 143-150. 
